\title{
PRODUCTION AND PRICE RELATIONSHIP FOR CHILLI IN BANGLADESH: AN EMPIRICAL ANALYSIS
}

\author{
M.K. Hasan* and M.K. Uddin \\ Spices Research Centre, Bangladesh Agricultural Research Institute \\ Shibganj, Bogra, Bangladesh
}

\begin{abstract}
Chilli price fluctuates more in every year in Bangladesh. Therefore, this crop is faced with the highest risk and uncertainty. Due to that, prediction is not possible on production correctly. The study was conducted to aim at the determination of fluctuation, and production-price relationship of chilli in Bangladesh. The experiment was carried out by using chilli area, production and prices data from Bangladesh Bureau of Statistics (19852014). Data were analyzed using simplest method for fluctuation, and the Koyck model of distributed lag models. The study showed that the extent of annual price fluctuation of chilli was identified which was between -55 to 111 per cent. Ten several causes were identified which have been the reason of unstable price of chilli. Government price control, improvement of production technology and other identified measures are urgently needed for preventing price fluctuation. According to the results, chilli production in Bangladesh has been influenced by the lag value of average price formed in the market. The most striking result of the study is that the time required for the changes in the chilli prices in Bangladesh to have an effect on chilli production is 6.09 years. The value of coefficient indicated that the changes in lag values of the prices had a positive influence on production, this influence was getting smaller. To reduce the risk and uncertainty of the price of chilli which caused fluctuation more, sustainable chilli farming and establishment of an efficient marketing organization is necessity.
\end{abstract}

Keywords: Chilli, fluctuation, price and production

\section{INTRODUCTION}

Chilli, an important spice crop of Bangladesh is widely grown both in winter and summer seasons. Area under chilli cultivation was 93.55 thousand hectares producing about 102.25 thousand tons in the year 2012-13 (BBS 2015). Chilli is used in green and dried forms. It is especially liked for its pungency, spicy taste and the appealing colour, it adds to the food (Mathukrishnan et al., 1993). Chilli is used as

\footnotetext{
*Corresponding author email: kamrulspc@yahoo.com
} 
pickles, sauces and other beverages (Purseglove et al., 1991). It has medicinal values also. It is a principal ingredient in the Bangladeshi kitchen as curry powder and paste.

Chilli is the crop in Bangladesh whose price fluctuates more in every year. Therefore, this crop is faced with the highest risk and uncertainty. Resulting this, prediction is not possible on production correctly. Besides, problems in chilli pricing also negatively affect the production since the prices of chilli produces are generally determined under market conditions. However, there is not an effective organization in the production and marketing of chilli in Bangladesh. Price of chilli is formed in domestic market conditions expanding upon the supply. Changes in the chilli prices result in fluctuations in the production. For this reason, farmers have to take the prices formed by the market as information and to make production plans accordingly. Prices in the market are formed based on supply and demand principles rather than production costs. The sensitivity of chilli farmers to prices in Bangladesh would be measured. Establishing the interaction between agricultural production and price via a distributed lag model, such a model can significantly contribute to the literature. Indeed, we have not come across with such an investigation into the subject.

Agricultural enterprises in Bangladesh are large. Farmers are not well organized in input and produce markets. Education level of farmers is low. All these factors make price uncertainties for the farmers in chilli market. Farmers consider the previous years' price when they plan to cultivate. Such a planning causes big price and production fluctuations in chilli markets. This is called Cobweb theory in economy literature, often encountered in agricultural production and has been the subject of the investigations about production amount and price relationships.

Because of this structural feature of chilli produces, relationship between the amount produced and the price can be studied using distributed lag model. In the regression models in which time series data were used, if the model uses not only the present values but also the delayed past values of the defining variable, this model is defined as distributed lag model (Gujarati, 2005). Two major problems arise in distributed lag models. One of them is multicolinearity and the other is the increasingly lowered degrees of freedom as lag length increases. In order to overcome these problems, Koyck model has been developed for the estimation of parameters in distributed lag models.

In a study conducted by Yurdakul (1998) in Turkey, relationship between the production and price of cotton crop in 1985-1997 periods was studied using Koyck approach. In another study by Dikmen (2005), production and price relationship for tobacco crop in 1982-2003 periods was analyzed using Koyck model. Eraktan et al. (2004) used Koyck model to investigate the relationship between Direct Income Support, a financial support paid by government to the farmers based on their agricultural land in Turkey, and value added produced. The study by Erdal (2006) dealt with the production and price in tomato crop in 1975-2004 period using Koyck 
approach. Another study by Ozcelik and Ozer (2006) studied wheat production and price relationship in 1973-2004 period using Koyck approach. Study conducted by Erdal and Erdal (2008) analyzed the relationship between dry onion production and price in 1975-2006 period via Koyck approach.

Such type of study was not performed before on chilli crop in Bangladesh by using Koyck model. Therefore, the study was undertaken to aim at studying the price fluctuation and, the production amount and price relationship of chilli, a staple spices to a large extent in Bangladesh, using Koyck model.

The overall objective of the study is to determine production and price relationship caused by fluctuation of chilli production in Bangladesh.

The specific objectives of the study are:

- To study the fluctuation of price and production of chilli; and

- To determine the relationship between the prices and production amount of chilli

\section{MATERIALS AND METHOD}

\section{Sources of data}

Both primary and secondary data were used for the study. Secondary data were collected from several issues of Bangladesh Bureau of Statistics (BBS) and Department of Agricultural Marketing (DAM). For the collection of primary data, three districts namely Bogra, Sirajgong and Gaibandha were selected purposively depending upon the concentration of production and commercially marketing of winter chilli.

\section{Sampling design and data collection}

The study was considered for the time period of 1985 to 2014 for time series analysis. Purposive and simple random sampling techniques were used to pick a primary sample. A total of 92 farmers and traders were selected randomly from the three areas. Primary data were collected by face-to-face interview through pretested structured questionnaires.

\section{Analytical technique}

The collected data and information were reduced to tabular form which included classification of tables into meaningful results. Except this, the following analytical techniques were used for the study.

\section{A. Fluctuation in price and production}

The inter year fluctuation in prices were estimated by the simplest method as percentage change in price year by year. It is estimated as 
M.K. Hasan and M.K. Uddin

$$
\Delta P_{t}=\frac{P_{t}-P_{t-1}}{P_{t-1}} X 100 \ldots \ldots \ldots \ldots
$$

Where, $\Delta \mathrm{P}=$ Percentage change in price in year $\mathrm{t}$ over the last period (year), $\mathrm{P}_{\mathrm{t}}=$ Current year's price in year $\mathrm{t}, \mathrm{P}_{\mathrm{t}-1}=$ Previous year's price in year $\mathrm{t}-1$

\section{B. Distributed Lag Model}

$$
Y_{t}=\alpha+\beta_{0} X_{t}+\beta_{1} X_{t-1}+\beta_{2} X_{t-2}+\ldots . .+\beta_{k} X_{t-k}+u_{t}
$$

Where, $\mathrm{Y}_{\mathrm{t}}$ is chilli production in period $\mathrm{t}, \mathrm{X}_{\mathrm{t}}$ is chilli price in period $\mathrm{t}$ and $\mathrm{X}_{\mathrm{t}-1}$ is chilli price in one period earlier than $\mathrm{t}$.

\section{Koyck Model}

$$
\mathrm{Y}_{\mathrm{t}}=\alpha(1-\lambda)+\beta_{0} \mathrm{X}_{\mathrm{t}}+\lambda \mathrm{Y}_{\mathrm{t}-1}+\mathrm{v}_{\mathrm{t}}
$$

Where, $Y_{t}$ is chilli production in period $t, X_{t}$ is chilli price in period $t$ and $Y_{t-1}$ is chilli production in one period earlier than $\mathrm{t}$.

\section{RESULTS AND DISCUSSION}

\section{Estimation of fluctuation}

The extent of annual price fluctuation of chilli was identified which was between -55 to 111 percent while the extend of fluctuation of area, production and yield ranged between -39 to $156,-27$ to 161 and -17 to 55 percent respectively during the study period. The extreme fluctuation of price takes place in the year 1991-92 and 2005-06 (Table 1). Excessive fluctuation of area and production of chilli in Bangladesh occurred in 1998-99 (Table 1). This was mainly due to getting higher price in the previous year tends to the farmer to increases chilli cultivation. Yield variability is caused by weather fluctuation and also for the insect and pest infestation diseases.

Table 1. Fluctuation of price, area, production, yield of chilli in Bangladesh for the period of 1985-86 to 2013-14

\begin{tabular}{l|c|c|c|c}
\hline \multicolumn{1}{c}{ Year } & Price & Area (ha) & Production & Yield ha $^{-1}$ \\
\hline $1985-86$ & & & & \\
$1986-87$ & 4.03 & -4.21 & -1.94 & 2.37 \\
$1987-88$ & -17.59 & 1.72 & 6.52 & 4.72 \\
$1988-89$ & 60.62 & 0.28 & 4.03 & 3.73 \\
$1989-90$ & 51.97 & 2.72 & 9.02 & 6.13 \\
$1990-91$ & 2.24 & 0.56 & 0.10 & -0.47 \\
$1991-92$ & -54.76 & -4.00 & -1.94 & 2.15 \\
$1992-93$ & 53.17 & -0.54 & 6.81 & 7.40 \\
\hline
\end{tabular}




\begin{tabular}{l|c|c|c|c}
\hline \multicolumn{1}{c}{ Year } & Price & Area (ha) & Production & Yield ha $^{-1}$ \\
\hline $1993-94$ & 31.17 & -0.77 & -0.98 & -0.21 \\
$1994-95$ & 9.13 & -0.58 & -2.86 & -2.30 \\
$1995-96$ & -26.16 & -0.26 & -0.43 & -0.18 \\
$1996-97$ & -27.52 & -0.48 & -0.91 & -0.44 \\
$1997-98$ & 101.31 & -0.01 & 1.28 & 1.30 \\
$1998-99$ & -8.56 & 155.99 & 160.99 & 1.95 \\
$1999-00$ & -24.78 & -0.01 & 0.62 & 0.63 \\
$2000-01$ & 9.51 & -0.22 & -1.65 & -1.44 \\
$2001-02$ & 2.07 & -3.32 & -3.99 & -0.69 \\
$2002-03$ & 48.52 & -0.06 & 1.01 & 1.08 \\
$2003-04$ & -24.22 & -5.32 & -2.64 & 2.83 \\
$2004-05$ & 0.19 & -5.44 & 40.24 & 48.30 \\
$2005-06$ & 111.19 & -8.59 & -18.93 & -11.31 \\
$2006-07$ & -7.14 & -0.67 & -0.33 & 0.34 \\
$2007-08$ & -33.30 & -39.43 & -27.04 & 20.46 \\
$2008-09$ & 62.93 & -2.87 & -5.73 & -2.94 \\
$2009-10$ & 9.02 & -1.96 & 0.15 & 2.16 \\
$2010-11$ & 28.42 & 17.59 & 14.81 & -2.37 \\
$2011-12$ & -15.61 & -0.39 & 1.33 & 1.73 \\
$2012-13$ & 5.45 & -4.38 & -21.09 & -17.47 \\
$2013-14$ & 7.53 & -30.83 & 7.50 & 55.42 \\
Extent of fluctuation & -55 to 111 & -39 to 156 & -27 to 161 & -17 to 55 \\
\hline
\end{tabular}

Average annual variability or random fluctuation of price of Bangladesh was measured by percentage deviation of actual prices from 3 years moving average. Average annual variability or random fluctuation of chilli prices was estimated; where 14 observations were found above the trend line (three years moving average) and 14 observations were found below the trend line out of 28 observations. The extent of random fluctuation was lower than the extent of annual fluctuation (Table 2). Lower price during the current year adversely affect next year's production and this uncertainty in supply causes price to be fluctuated to a great extent.

\section{Causes of price fluctuation of chilli crop}

Especially in the least developed countries, the agricultural commodities markets have frequently experienced extreme price fluctuations which often cause 
Table 2. Random fluctuation of harvest price of chilli for the period from 1985-86 to 2013-14 in Bangladesh

\begin{tabular}{|c|c|c|c|}
\hline Year & Harvest price & $\begin{array}{c}3 \text { years moving } \\
\text { average }\end{array}$ & $\begin{array}{c}\% \text { of deviation from } \\
\text { actual price }\end{array}$ \\
\hline $1985-86$ & 26869 & & \\
\hline $1986-87$ & 27953 & 25953 & 7.71 \\
\hline $1987-88$ & 23036 & 29330 & -21.46 \\
\hline 1988-89 & 37001 & 38756 & -4.53 \\
\hline 1989-90 & 56230 & 50241 & 11.92 \\
\hline 1990-91 & 57492 & 46577 & 23.43 \\
\hline 1991-92 & 26010 & 41114 & -36.74 \\
\hline $1992-93$ & 39840 & 39370 & 1.19 \\
\hline 1993-94 & 52260 & 49710 & 5.13 \\
\hline 1994-95 & 57030 & 50467 & 13.01 \\
\hline 1995-96 & 42110 & 43220 & -2.57 \\
\hline 1996-97 & 30520 & 44690 & -31.71 \\
\hline $1997-98$ & 61440 & 49380 & 24.42 \\
\hline 1998-99 & 56180 & 53293 & 5.42 \\
\hline 1999-00 & 42260 & 48240 & -12.40 \\
\hline 2000-01 & 46280 & 45260 & 2.25 \\
\hline 2001-02 & 47240 & 54560 & -13.42 \\
\hline 2002-03 & 70160 & 56857 & 23.40 \\
\hline 2003-04 & 53170 & 58867 & -9.68 \\
\hline 2004-05 & 53270 & 72980 & -27.01 \\
\hline 2005-06 & 112500 & 90080 & 24.89 \\
\hline 2006-07 & 104470 & 95550 & 9.34 \\
\hline 2007-08 & 69680 & 95893 & -27.34 \\
\hline 2008-09 & 113530 & 102327 & 10.95 \\
\hline 2009-10 & 123770 & 132083 & -6.29 \\
\hline 2010-11 & 158950 & 138950 & 14.39 \\
\hline 2011-12 & 134130 & 144840 & -7.39 \\
\hline $2012-13$ & 141440 & 142553 & -0.78 \\
\hline 2013-14 & 152090 & 146765 & 3.63 \\
\hline $\begin{array}{l}\text { Range of } \\
\text { fluctuation }\end{array}$ & - & - & -37 to 25 \\
\hline
\end{tabular}


severe supply problems. Based on that, the study explored to determine the various causes of price fluctuation of chilli products. The results are shown in figure 1 .

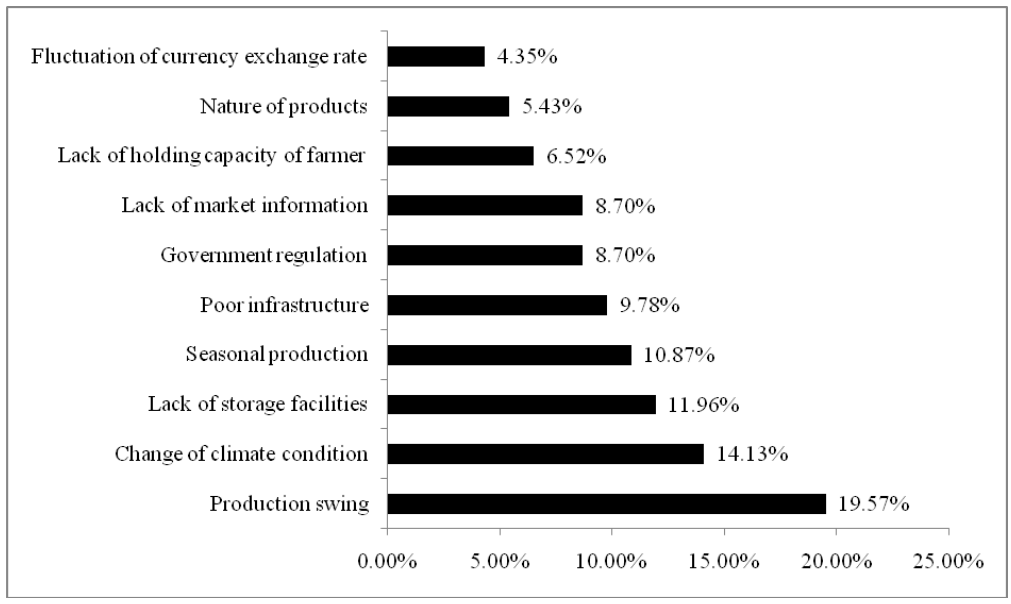

Figure1. Causes of price fluctuation of chilli in Bangladesh

Production swing: The main cause of price swing of chilli was occurred by production swing. Causes of low productions were performed not to use of improved variety and other production technologies by the farmers. When poor technology is use in production, price tends to raise compare to improve technologies. Used in improved technology reduces total cost of production. Due to low production, supply of chilli became low comparatively to the demand of consumer in the market. Resulting this, chilli price becomes high. About $19.57 \%$ respondent argued that, price fluctuation was performed by production swings.

Change in climate condition: Production of chilli depends on optimum rainfall and temperature. Adverse climatic condition reduces the yield of chilli drastically. Due to that, supply of chilli in the market becomes low and price tends to high. On the other hand, changes in optimum climatic condition enhance the huge supply of chilli and price tends to low. The reason of price fluctuation mentioned by $14.13 \%$ respondent due to change in climatic condition.

Lake of storage facility: It was argued by $11.96 \%$ respondent that the technological development of storage among small scale farmers is still poor and this adversely reduces the quality of chilli and the storage loss becomes high. When poor storage technology is used in production, supply reduces and price tends to raise compare to improved technologies.

Seasonal production: About $10.87 \%$ respondent pointed out that seasonal productions are also another causative factor for price fluctuation of chilli. Most agricultural products are seasonally produced which cause unequal balance of the availability of it and for this reason, price tend to be low during bumper production 
period and to be high during scarcity time. For this reason, price of chilli became rise and fall in different periods.

Poor infrastructure: Furthermore, $9.78 \%$ respondent commented that poor infrastructure is one among the causes of price fluctuations. There are high differences in level of appropriateness of roads in this country which make the ever changing of prices for chilli from time to time around the year especially during the rainy season. In this season, most supply areas are not reached easily which causes price to rise.

Government regulation: It was also established by $8.70 \%$ respondent that Government regulation and policies does not provide a conducive environment to farmers, this is because when farmer harvests chilli then government allows importation of this product. Resulting this, importation badly affect the price sustainability of domestic price of chilli.

Lack of market information: Lack of market information is another cause for price fluctuation of chilli. $8.70 \%$ respondent argued that they do not know about the secondary and terminal market information. So a big gap of price was observed in farm gate and retailer price.

Lack of holding capacity of farmer: Small farmers are not able to hold their chilli up to higher price level in the market due to shortage of cash money and $6.52 \%$ of respondent opined that lack of holding capacity of farmer is a cause of price fluctuation.

Nature of products: Nature of products was also pointed out by $5.43 \%$ respondent as another cause of price fluctuations of chilli. It was established that most agricultural products are perishable in nature which influences the rise and fall of price over time. The perishability nature of some agricultural product makes it difficult to store during plenty in time hence farmers has to sell them even when the price is still low.

Fluctuation of currency exchange rates: It was argued that the unstable fuel prices cause everything else including farm products to fluctuate more often due to high cost of transporting the farm product from the farm area to the markets. Besides, fluctuation of currency exchange rates makes the import price unstable and market prices to fluctuate, $4.35 \%$ respondents opined it.

\section{Measures to prevent price fluctuation of chilli products}

There are various measures can be implemented to control price fluctuations in order to support the domestic price of chilli products as shown in figure 2 below. About $20 \%$ of the respondent reported that the government step is the major solution to resolving the problem of price fluctuations of chilli through the fixation of import time during the scarce period and avoiding import during harvest period, and by setting a minimum price that discourage imports and results domestic product which will ultimately fetch better prices. It was further argued that, when the government restricts selling of chilli outside, resulted into larger accumulation of stocks while 
demand is low, this situation makes the price to go down. Improvement of farming and other infrastructures was identified by $12 \%$ respondents, small scale

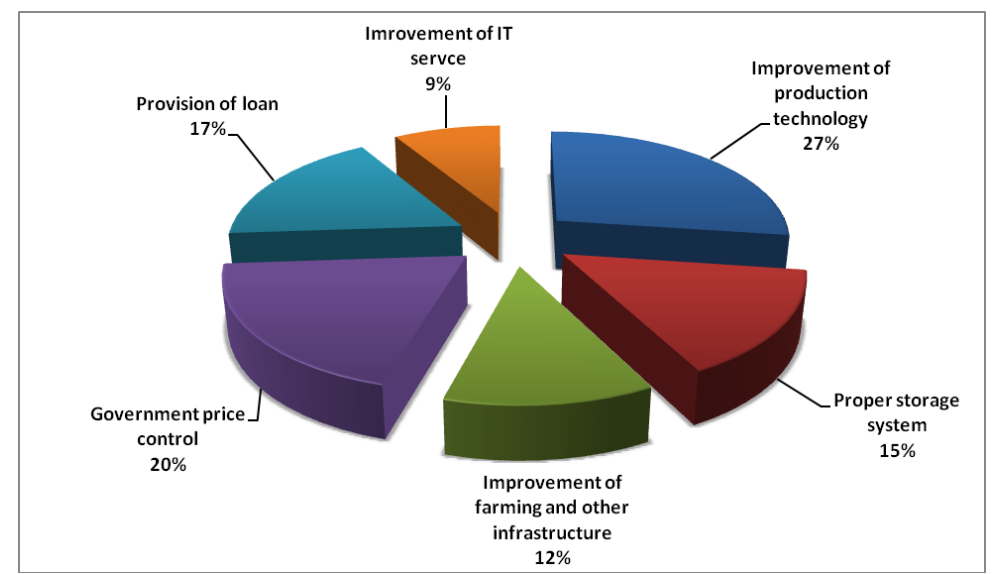

Figure 2. Measures to prevent price fluctuation of chilli in Bangladesh

farmers use poor farming tools which requires more labor force which results in high production costs. About 17\% respondent commented that, provision of loan is very important in stabilizing prices and gaining control over the market and the economy of the country at larger. Again, 9\% respondent gave opinion IT (Information Technology) service should be developed up to village. So, that the farmer and trader are able to know the market information easily. To control the excessive price of chilli, much production is needed. At the point of interview $27 \%$ respondent said improved variety and other production technology should be reached to the small and medium scale farmer. Lastly proper storage system was mentioned by $17 \%$, having proper storage system farmers will be able to preserve their surplus and hence balance price will be maintained throughout the season.

\section{Estimation of the relationship between chilli prices and production}

In order to determine the relationship between chilli prices and production during the studied period, a correlation analysis was performed. A correlation coefficient of 0.70 was found, indicating a high level of relationship between the two variables. This result indicated that production amount and price relationship can be studied using Koyck model.

Distributed lag model was formed as follows:

$\mathrm{Q}_{\mathrm{t}}=\alpha+\beta_{0} \mathrm{P}_{\mathrm{t}}+\beta_{1} \mathrm{P}_{\mathrm{t}-1}+\beta_{2} \mathrm{P}_{\mathrm{t}-2}+\ldots \ldots \ldots+\beta_{\mathrm{k}} \mathrm{P}_{\mathrm{t}-\mathrm{k}}+\mathrm{u}_{\mathrm{t}}$

In the model, $Q_{t}$ is chilli production (ton) in period $t, P_{t}$ is chilli price in period $t$ (Tk/ton). In order to form Koyck model, it is necessary to determine lag value of chilli price series lag length. 
M.K. Hasan and M.K. Uddin

In a distributed lag model, Schwarz information criterion (SIC) was used to determine the lag length Dikmen, 2005).

Schwarz proposes reduction of equation (5) to the lowest:

$\mathrm{SIC}=\ln \sigma^{2}+\mathrm{m} \ln \mathrm{n}$

Here, $\sigma^{2}$ is the highest probability estimate of $\sigma^{2}=(\operatorname{RSS} / n), m$ is length of the lag, $n$ is the number of observations and RSS is the residual sum of square. In summary, a regression model is used along with some lag values $(=m)$, and $\mathrm{m}$ value that makes the value of Schwarz criterion the lowest is selected (Gujarati, 2005). At this stage, without making any limitation to the form of the distributed lag, a very large $\mathrm{k}$ value length of the lag is used at the start. Then, when the duration of lag is shortened, whether the model goes wrong is checked (Davidson and Mackinnon, 1993).

Values for Schwarz criterion determined at different lag lengths for Equation (5) is given in table 3. As can be seen from the table, the lowest Schwarz value (24.25) was obtained from lag length $\mathrm{K}=1$. Thus, the effect of chilli prices on chilli production is zero after one year. According to the determined lag lengths, the relationship between chilli production and price has been estimated using the classical least squares method given in Equation (4). The results of the model are given in table 4 .

The results show that chilli prices in the period $t$, one (t-1) and two periods earlier ( $\mathrm{t}-2)$ positively affected the chilli production while chilli prices three periods earlier (t-3) negatively affected the production. Partial regression coefficients in the model except $\left(\beta_{0}\right)$ have been statistically insignificant. Model, as a whole, is also statistically significant. Multiple determination coefficient of the model is 0.62 , which means that $62 \%$ of the changes in chilli production can be explained through changes in chilli price and its distributed lag values.

Although statistically significant as a whole, the model has to be questioned in terms of reliability for two points related to distributed lag models. The first is the multiple relationship problems as a result of the fact that lag values of price variable was used in the model. The second problem is the loss of observations occurred in lag value set. If the number of data in formed series is not large, estimated values can be inconsistent due to lags.

In order to overcome these two major problems, estimations were made using Koyck model. Estimation results of regression equation given in table 4 based on Koyck model are given in table 5.

The results in Koyck model given in table 5 show that one taka increase in chilli price increased the chilli production by 0.014 tons. But the coefficient was statistically insignificant. An increase of one tons of chilli production in the previous period increased the chilli production by 0.859 tons. According to mean lag number, the time required for changes in chilli prices to have a significant and detectable 
effect on chilli production was 6.09 years. This result shows that Bangladesh farmers, who most often grow chilli as a staple spice crop, are very enthusiastic for growing chilli.

Table 3. Lag length values based on Schwarz criterion

\begin{tabular}{c|c|c}
\hline Sl. No. & Lag length & Schwarz values \\
\hline 1. & $\mathrm{~K}=1$ & 24.25 \\
2. & $\mathrm{~K}=2$ & 27.70 \\
3. & $\mathrm{~K}=3$ & 31.09 \\
4. & $\mathrm{~K}=4$ & 34.40 \\
5. & $\mathrm{~K}=5$ & 37.62 \\
\hline
\end{tabular}

Table 4. The results of distributed lag model

\begin{tabular}{|l|l|l|l|l|l|}
\hline \multirow{2}{*}{ Items } & \multicolumn{5}{|c|}{$\mathrm{Q}_{\mathrm{t}}=51879.09+0.327 \mathrm{P}_{\mathrm{t}}+0.196 \mathrm{P}_{\mathrm{t}-1}+0.027 \mathrm{P}_{\mathrm{t}-2}-0.142 \mathrm{P}_{\mathrm{t}-3}$} \\
\cline { 2 - 6 } & \multicolumn{5}{|c|}{ Lag length } \\
\cline { 2 - 6 } & Constant & $\mathrm{t}$ & $\mathrm{t}-1$ & $\mathrm{t}-2$ & $\mathrm{t}-3$ \\
\hline Coefficient & 51879.09 & 0.327 & 0.196 & 0.027 & -0.142 \\
\hline t-values & 4.026 & 0.862 & 0.489 & 0.068 & -0.357 \\
\hline Probability & 0.000 & 0.396 & 0.629 & 0.946 & 0.724 \\
\hline \multicolumn{7}{|c|}{$\mathrm{R}^{2}=0.62$} & $\mathrm{~F}=4.916$ & $\mathrm{P}=0.01$ & \multicolumn{3}{c|}{$\mathrm{DW}=0.349$} \\
\hline
\end{tabular}

Table 5. The results of Koyck model

\begin{tabular}{|l|l|l|l|}
\hline \multirow{2}{*}{ Items } & \multicolumn{3}{|c|}{$\mathrm{Q}_{\mathrm{t}}=11420.30+0.014 \mathrm{P}_{\mathrm{t}}+0.859 \mathrm{Q}_{\mathrm{t}-1}$} \\
\cline { 2 - 4 } & \multicolumn{3}{|c|}{ Lag length } \\
\cline { 2 - 4 } & Constant & $\mathrm{t}$ & $\mathrm{Q}_{\mathrm{t}-1}$ \\
\hline Coefficient & $\alpha) 11420.30$ & $\beta) 0.014$ & $\lambda) 0.859$ \\
\hline t-values & 1.542 & 0.152 & 8.549 \\
\hline Probability & 0.134 & 0.880 & 0.000 \\
\hline \multicolumn{1}{|c|}{$\mathrm{R}^{2}=0.78$} & $\mathrm{~F}=52.07$ & $\mathrm{P}=000$ \\
\hline Koyck Model: Mean lag & 6.09 & $\mathrm{DW}=2.123$ \\
\hline
\end{tabular}

Note: $Q_{t}$ is chilli production in period $t, P_{t}$ is chilli price in period $t$ and $Q_{t-1}$ is chilli production in one period earlier than $\mathrm{t}$.

Mean lag $=\frac{\lambda}{1-\lambda}$

Different crops the time required for the prices to have considerable changes is 1.19 years for tobacco (Dikmen, 2005), 18 years for tomato (Erdal, 2006), 0.83 years 
for wheat (Ozcelik and Ozer, 2006) and 1.19 years for dry onion (Erdal and Erdal, 2008) in Turkey.

In Koyck model

$\mathrm{Q}_{\mathrm{t}}=\alpha+\beta_{0} \mathrm{P}_{\mathrm{t}}+\lambda \mathrm{Q}_{\mathrm{t}-1}+\mathrm{u}_{\mathrm{t}}$ and $\beta_{\mathrm{k}}=\lambda^{\mathrm{k}} \beta_{0}$

Since $0<\lambda<1$, using the following calculations Equation (14) is reached;

$\beta_{0}=\lambda^{0} \beta_{0}=(0.859)^{0}(0.014)=0.0140$

$\beta_{1}=\lambda^{1} \beta_{0}=(0.859)^{1}(0.014)=0.0120$

$\beta_{2}=\lambda^{2} \beta_{0}=(0.859)^{2}(0.014)=0.0103$

$\beta_{2}=\lambda^{3} \beta_{0}=(0.859)^{3}(0.014)=0.0089$

$\alpha_{0}=\alpha /(1-\lambda)=11420.30 /(1-0.859)=80995.04$

When the regression formulae derived from Koyck model is rewritten using this results, equation (6) is obtained;

$\mathrm{Q}_{\mathrm{t}}=80995.04+0.0140 \mathrm{P}_{\mathrm{t}}+0.0120 \mathrm{P}_{\mathrm{t}-1}+0.0103 \mathrm{P}_{\mathrm{t}-2}+0.0089 \mathrm{P}_{\mathrm{t}-}$

In Equation (6), which represents a distributed lag model derived from Koyck model, it is seen that lag chilli prices have a decreasing effect on chilli production, since $0<\lambda<1$. Decreasing effects of lag price parameters result from the fact that $\lambda$ coefficient exerts an effect which was limited in the model.

According to Equation (6), a one-unit increase in chilli prices in Bangladesh increased the production by 0.0140 tons in that year while a one-unit increase in the previous year increased the production by 0.0120 tons. In addition, a one-unit price increase two years ago increased the production by 0.0103 tons. On the other hand, a one-unit price increase three years ago increased the production by 0.0089 tons. Although the changes in lag values of the prices had a positive influence on production, this influence was getting smaller.

\section{CONCLUSIONS AND SUGGESTIONS}

The results of the study depicted that a remarkable extent of price and production fluctuation was occurred in chilli. The study identified several causes which have been the reason of unstable price of chilli as change in production swing, climatic condition, lack of storage facilities, seasonal production, poor infrastructures, government regulation, lack of market information, lack of holding capacity of farmers, nature of products and fluctuations of currency exchange rate.

The relationship between amount of chilli produced and marketed, and price of chilli, all under domestic market economy conditions, were studied. There was a positive correlation of $70 \%$ between amount produced and the price. This coefficient showed that Koyck model was appropriate for studying the relationship between production amount and price of chilli crop. 
For the estimation of unknown parameters in the model, lag length determined using Schwarz criterion was calculated as one. This means that chilli production is influenced by the prices of up to past one year in Bangladesh. According to Koyck model, the time required for the changes in chilli prices to have a significant and detectable effect on chilli production was calculated as 6.09 years.

For the studied period, one-unit increase in chilli prices increased the chilli production by 0.0140 tons in that year; while a one-unit increase in the previous year increased the production by 0.0120 tons. In addition, a one-unit increase in the prices of two years ago increased chilli production by 0.0103 tons. On the other hand, a one-unit price increase three years ago increased the production by 0.0089 tons Thus, it can be said that each additional lag value results in a smaller effect on chilli production.

For sustainable chilli farming in Bangladesh, establishment of an efficient marketing organization is a necessity. The study also identified several measures of preventing price fluctuation viz., government price control, improvement of farming and other infrastructures, provision of loan and subsidies, improvement of IT service, improvement of production technology, proper storage system, etc.

For the chilli crop, it is necessary to conduct a contract based production system. Policies are needed to be developed for efficient, profitable and sustainable chilli farming. Thus, price uncertainties that the producers face can be overcome, and contribution of this major spice crop to national economy can be increased.

\section{REFERENCES}

BBS.1980 to 2015. Statistical Yearbook of Bangladesh. Bangladesh Bureau of Statistics, Planning Division, Ministry of Planning, Dhaka

Davidson, R. and Mackinnon, J.G. 1993. Estimation and inference in econometrics, New York, Oxford university pres., ISBN 0-19-506011-3, pp. 675-676

Dikmen, N. 2005. The relationship tobacco and price with koyck-almon approach, VII. National econometrics and statistical symposium, 26-27 May, Ýstanbul University. Available at http:// www.ekonometridernegi.org/bildiriler/o16s1.pdf.

Eraktan, G., Abay, C., Miran, B. and Olhan, E. 2004. Direct income support and results in promote of agriculture in Turkey. Publication of Istanbul Chamber of Commerce, 53: 68-71

Erdal, G., 2006. The analysis of the relation between production and price in agricultural products with Koyck model (tomato case). Journal of Agricultural Faculty of Gaziosmanpasa University, 23: 17-24

Erdal, G. and Erdal, H. 2008. The interaction between production and prices for dry onion. Journal of Agricultural Faculty of Gaziosmanpasa University, 25: 33-39

Gujarati, D.N. 2005. Basic Econometrics. Fourth Edition, Tata McGraw-Hill Edition 
Koyck, L.M. 1954. Distributed Lags and Investment Analysis. North Holland Publishing Company, Amsterdam, pp. 21-50

Mathukrishnan, C.R., Thangaraj, T. and Chatterjee. 1993. Chilli and Capsicum. Vegetable Crop, Naya Prakash, Calcatta, India, pp.334-374

Ozcelik, A. and Ozer, O.O. 2006. Analysis of Correlation of Wheat Production and Prices with Koyck Models in Turkey. Journal of the Agriculture Sciences of Ankara University, 12: 333-339

Purseglove, J.W., Brown, E.G., Green, C.L. and Robins, S.R.J. 1991. Spices (Vol. 1), Longman Group UK Limited, Longman House, Burnt Mill, Harlow, EssexCM20 2JE, England

Yurdakul, F. 1998. The econometrics analysis of relationships between of cotton production and prices: Koyck Almon approach. Journal of Faculty of Economics and Administrative Sciences of Cukurova University, Vol. 8(1) 